\title{
PREVENTIVE POTENTIAL OF A CITY TERRITORIAL COMMUNITY CONCERNING SOCIAL ORPHANHOOD PREVENTION
}

\author{
Larysa Kal'chenko \\ Department of Post-doctoral student at Social Pedagogy \\ Taras Shevchenko National University of Luhansk \\ 1 Gogol sq., Starobilsk, Luhansk Region, Ukraine, 92703; \\ Sub-department of Special Education and Inclusion \\ Ivan Franko National University of Lviv \\ 1 Universytetska stк., Lviv, Ukraine, 79000 \\ larysakalchenko@gmail.com
}

\begin{abstract}
In the article the author reveals such concepts as "territorial community of a city", "preventive potential", "social capital", "resourceful environment of a territorial community" in the context of social orphanhood prevention. Also in the research is presented author's interpretation of the concept of "territorial community of a city" as a complex self-manageable social system of self-organizing local communities (city quarters, areas of a big city etc.), members of which are individuals, governmental and non-governmental social organizations, non-commercial social organizations, neighborhoodhood groups and other microstructures united by common interests, goals and activity for treating own needs (everyday life, habitat, leisure time, education, communication) and localizations of possible of social risks, also solving of a problems of a territory.

Characteristic features and features of effective functioning of territorial community are defined, among which are the following: presence of individual (separated members of a community) and collective subjects (network of public and governmental organizations, social groups, neighborhoodhood unions etc.), their activity and degree of involvement in solving problems, character of interaction and permanence of connections between subjects (network of social interaction), availability of necessary resources of territorial community (as institutional, human, spiritual, time, material, administrative ones), territorial-cultural specificity of a community.

In the article the author defines subjects of a community, which have preventive potential (resource) concerning social orphanhod prevention in a territorial community of a city. The author also justifies the importance of creation of a resourceful environment of a territorial community of a city for prevention of family discomfort and neglection as well as homelessness of children, defines techniques of active involvement of community residents into solving of social problems including social orphanhood. Author also reveals forms and methods of activation of a community for social orphanhood prevention.
\end{abstract}

Keywords: territorial community of a city, social orphanhood prevention, subjects of a community, preventive potential.

\section{Introduction}

For most civilized countries of the world the number of social orphans is a direct indictor of social-economic and spiritual-moral health of a nation, and the lower this number, the better condition of family and children in these countries is. At the modern stage of the development of the Ukrainian society, transformation of family organization, and in fact, a crisis of an institute of family and marriage, widening of cohabitation, adulterate natality, change of value principles, socio-economic problems, impoverishment of the population and war in the East of the country became a catalyst of increasing the number of social orphans. Thus, for May of 2018 the total number of social orphans in the country was 106 thousand 700 children. Among them only 8174 have a status of children-orphans and children, deprived of parental care, that is $8.7 \%$ of the total number of children in boarding schools. All other pupils - 98526 children [1] - are ones, whose parents are alive, but deprived of parental rights. The ministry of social policy of Ukraine names among the main causes of this phenomenon the practical absence of services at the local level for supporting families with children, which are in difficult life conditions, insufficient work, directed on giving timely help to these families [2]. So, a conclusion is obvious! Under the pressure of more economically complicated, but democratic life conditions, involvement of local communities, mobilization 
of their resources and taking responsibility for the development of a territory by them become an important necessity for dwellers themselves, for politicians and also for specialists, practicians and scientists, who study this process and offer innovative approaches of its optimization.

Analyzing scientific studies, we pay attention to the fact that among urgent questions of the scientific search, in the context of our study, is a problem of definitive discourse as to understanding the essence of the notions «community» [3, 4], «territorial community» [5, 6], its main signs $[4,7]$, functions and peculiarities from the aspects of different scientific branches $[8,9]$; scientific works, devoted to the problem of community development from the position of professional social work $[10,11]$, use of the subject approach as to the process of community development and use of the individual potential of community-members, their involvement in affairs and life of a territory [12, 13]; theoretical and practical aspects of the activity of governmental $[14,15]$ and public institutions $[16,17]$ as to optimization of the process of de-institutionalization of children-orphans and ones, deprived of parental care [18], problem of state regulation of the process of social orphanhood prevention [19] and interdepartmental interaction between subjects of a territorial community [20, 21], elucidation of innovative technologies of social and socio-pedagogical work with problem families and children [22], questions of active involvement of local communities in solving social problems of the population $[23,24]$ and other. But, as it is demonstrated by the analysis of scientific works, the question of activity of a city territorial community as to social orphanhood prevention is not elaborated that conditioned the choice of the problem of this study.

\section{Aim and tasks of research}

The aim of the article is in elucidation of a preventive potential of a city territorial community as to social orphanhood prevention by determining main subjects of a city community and their functional resources as to preventing causes of family troubles and phenomena of social orphanhood, child neglect and homelessness.

\section{Materials and methods}

The experimental-research work on probation of a model of social orphanhood prevention in the city territorial community was started by us in December of 2012 in Lugansk city within realizing the international project "Program of support of families and protection of child rights "SOS Children's village", started in 2012 in the territory of today occupied Lugansk region (supported by the Lugansk regional department (LRD) of the International charity organization (ICO) of "Charity fund (CF) «SOS Children's Villages International» (Austria), where was created the Social center of family strengthening that became in fact a coordination center of the process of social orphanhood prevention in the city territorial community and the Scientific-methodical consultation center for social orphanhood prevention (SMCCSOP) at the department of social pedagogy of Lugansk national university, named after Taras Shevchenko, that realized the scientific-methodological support of the project, and Coordination council on questions of social orphanhood and family trouble prevention in the city council. But as a result of the difficult socio-political situation and beginning of combat actions in the East of Ukraine, the further realization of the project of social orphanhood prevention took place under conditions of the territory community of Starobilsk city of Lugansk region, where the Social center of family strengthening of the Lugansk region department of ICO, “CF "SOS Children's village" was opened from October of 2014. And already from March of 2015 to December of 2017 within the project activity of the Social center of family strengthening of LRD of ICO, "CF "SOS Children's village" the probation of the project of social orphanhood prevention was continued under conditions of the territory community of Starobilsk city in the north of Lugansk region.

Main methods of this study are: theoretical cognition - analysis, synthesis, systematization, classification, generalization for elucidating the content of basic notions of the study, substantiation of the essence of the process of social orphanhood prevention under conditions of a city territory community; empirical: diagnostic (methods of interrogation - questionnaire, interview, focus-groups), method of mapping a community, socio-pedagogical experiment as to elucidating the preventive potential of a city community and monitoring, for studying the condition of the 
investigated problem; statistical (qualitative and quantitative processing of data using methods of mathematical statistics for comparing and confirming obtained research results).

\section{Genesis and conceptual basis of the study}

Elucidating the aim and tasks of the study, it must be noted, that the question of involving the public for preventing and solving existing social problems has been an effective strategy of state management since ancient times, inherent not only to foreign communities of different world countries, but also to the Ukrainian community since the times of existence of the state Kyiv Rus, where the matter was a social model of "help (care) by the whole world" that is association of the city community for solving different social problems".

The interest to the modern community as a subject of social relations appeared in Ukraine already in II half of 90-ies of XX century, when the term "territorial community" was introduced at the legislative level in art. 140 of the Ukrainian Constitution (28.06.1996), and gained more content filling already in the law "About local self-government in Ukraine" (21.05.1997), as a result of activation of the process of civic society formation. The question of a community work as a practical method of realization of the state social policy at places became a research subject of the Ukrainian scientific community only at the beginning of 2000s. The active involvement of a community to the process of solving social problems of a territory started only from 2014 as a result of the beginning of the reform of power decentralization and acceptance of the Conception of the reform of local self-government and territorial organization of power (01.04.2014), Ukrainian laws «About cooperation of territorial communities» (17.06.2014) and «About voluntary association of territorial communities» (05.02.2015). This all gradually allowed to creation, according to statements of the European charter of local self-government, the essential active and effective institute of local self-government of the base level - united territorial communities (UTC). In fact, due to these actions, local authorities received possibilities of independent distribution of financial resources of a community and priority choice of public initiatives of solving social problems of a territory.

Talking about a city territorial community, we understand a complicated self-managed social system of self-organizing local authorities (districts, quarters (micro-districts of a city), which members are physical persons (separate citizens), governmental and private social institutions, non-commercial public organizations, neighborhood groups and other microstructures, united by common interests, aims and activity for satisfying own needs (connected with routine life, living environment, leisure, education, upbringing, communication) and localizing social risks, solving actual problems of a territory. An important characteristic of the function capacity of a city territorial community is the activity of its subjects and their potential.

Revealing the essence of the preventive potential of a city territorial community as to social orphanhood prevention, it is necessary to note that social orphanhood prevention under conditions of a city territory community is a system of complex arrangements of subjects of a territorial communityis a system of complex arrangements of subjects of a territorial community (individual (separate active dwellers) and collective (social institutions, private non-commercial organizations, neighborhood groups and other microstructures)), aimed at preventing the development of troublea situation of family and revealing and localizing causes, provoking difficult life conditions of a family and risks of social orphanhood, overcoming them at the stage of first crises by activating resources of a family itself and community for preventing a situation of refusal of a child or its neglect or homelessness.

Considering a city territorial community as an environment of social orphanhood prevention, main subjects of socio-pedagogical prevention in it may be: state and municipal and also private institutions of pre-school, general secondary, professional-technical and higher education; organs and institutions of social support of families, children and youth (commissions on questions of children's rights protection, services in children's affairs), social centers of different property forms, among which: centers of social services for families, children and youth centers of socio-psychological help; social center of mother and child; centers of socio-psychological rehabilitation of children (shelters for children); social hostels for children-orphans and ones, deprived of parental care; centers "Strengthening the Family"; crisis centers; centers of communities' de- 
velopment; resource centers and so on; culture institutions, which activity is directed on creating conditions for providing the development of human creativity and satisfaction of intellectual, spiritual, cultural needs of citizens; medical institutions and establishments, namely: women consulting centers and childbirth houses, schools of responsible parenthood at them; youth-friendly clinics at city polyclinics and family doctors; prevention organs of the National Police, subdivisions of juvenal prevention (subdivisions of the Ukrainian National Police in children's affair); citizens' associations, private non-commercial organizations, neighborhood associations, clubs of responsible parents, volunteers and so on, that provide social support and assistance to children, youth and families as a priority aim of their activity. Socio-pedagogical work on social orphanhood prevention under conditions of a city territorial community is a type of preventive activity of subjects of a territorial community, directed on creating the social support environment of children (separate person) and families of risk groups of social orphanhood within a city territorial community by organizing educational (enlightening), upbringing, socio-psychological, recreational, socio-legal, socio-routine conditions and measures, by activating interactions between community subjects and involving both resources of public and governmental institutions and internal ones of a family itself and person in this process

\section{Experimental procedures and results}

Based on the aforesaid conceptual principles of the social work as to social orphanhood prevention under conditions of a city territorial community, elucidating the aim and continuing the study, it is necessary to note that it is rather difficult to create an active community at the territory of a big city. That is why it is expedient to concentrate on the development of neighborhoodhood communities, mainly created at dwelling paces of humans, being a component of the system of local self-government, part of a city, fragment of a city culture [25, p. 9]. Such neighborhood communities must be created on the base of common interests of persons that live close to each other or separate problems of the local level that cause difficulties or discomfort for their life activity [26, p. 51].

Taking into account the aforesaid, organization and conduction of the experimental research work in solving one of the research tasks, namely - the study of the preventive potential of a city territorial community and activation of its subjects, provided:

1) creation of mobile information-diagnostic groups ("MID groups") of specialists of the Social center of family strengthening, Scientific-methodical consultation center for social orphanhood prevention, social pedagogues, specialists on social work of Center of social services for families, children and youth (CSSFCY), students of 3-4 courses of the specialty " Social work. Social pedagogy", teachers of secondary schools, volunteers - active dwellers of a community;

2) diagnostics of a local community of city micro-districts, their neighborhood communities (dwellers of many apartment houses and housing private sector) for creating a single base of socially vulnerable families and elucidation of the knowledge level of community-members as to establishments and institutions of the social-supporting type, placed at the territory of a community, that may satisfy demands and needs of dwellers of a city community, estimation of these needs;

3) analysis of the institutional space of a city territorial community (by the method of community mapping) and creation of a map of social institutions of a city territorial community for social orphanhood prevention that presents a net of governmental and public institutions of the social-supporting character that may give both preventive services and qualified help in a case of a life crisis of a family or its separate member;

4) realization of the information-educational work with the community population as to acquainting with a net of institutions of the social-supporting character by target conferences, social advertising in mass media (cards, booklets, calendars of good acts, prevention maps "By three steps ahead!", TV videos, internet-pages and so on), individual work, outclass information actions of social institutions of help and support in paces (in a community), within days of micro-districts, thematic holidays in a community, prevention days "On guards!", social sales, workshops, public quests for youth, meetings with heads of associations of co-owners of many apartment houses (SOMH), "quarter" streets and with the purpose of involving community residents in preventive activities and activating their potential resources. 
It is necessary to note that the volume of this publication, unfortunately, doesn't allow to stop in detail on the whole complex of questions, connected with methods, technologies and practices of activation of the social orphanhood prevention work in a city territorial community, realized by us within the project of social orphanhood prevention in 2012-2017. Just that we'll touch the diagnostic stage of the experimental work as to studying the preventive potential of a city territorial community - the stage of diagnostics of the local community of two micro-districts of Lugansk city (micro-districts Sazonov and Mala Vergunka), their neighborhood communities, realized by mobile information-diagnostic groups ("MID groups") and present the description of the obtained diagnostic results.

At the stage of diagnostics of the local community of two micro-districts of city Lugansk (in 2012) five "MID groups" interrogated 449 dwellers of many apartment houses and ones of the private sector of a micro-district, and also 677 parents of pupils of two secondary schools, included in the general sample totality of the experimental-research work of 1126 participants.

The start task of "MID group" was the interrogation by questioning the inhabitants of multi-apartment buildings and the streets of the micro-district and also the questionnaire of parents of two schools of the micro-district at parents' meetings. 7 questions, answers to which were fixed using a questionnaire blank, were presented to their attention (content of questions and example of a blank are given in Table 1).

Table 1

Example of a questionnaire blank

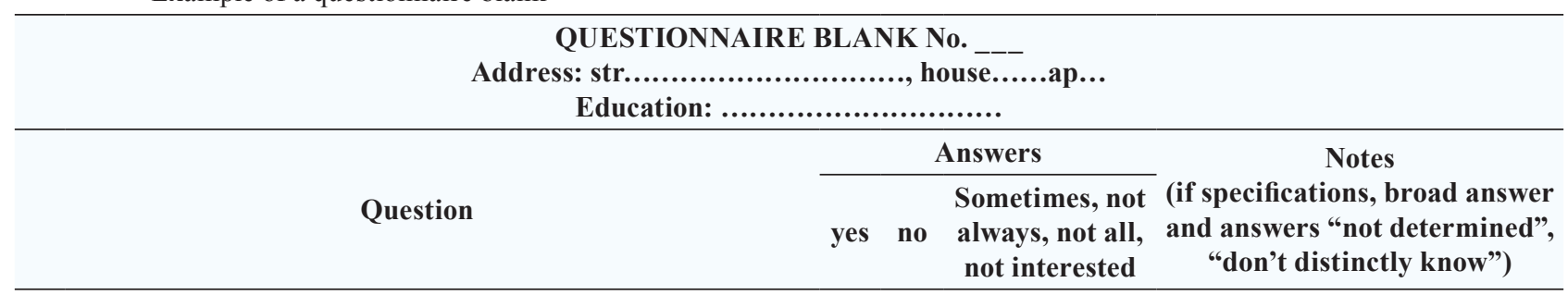

Do you (or you family) have any complications, non-mate-

rial problems who need third-party help in solving them? If

1 „yes", then name what exactly (communication with children, mutual understanding between family members, violence, invalidism, disease of close people, other)?

Do you know, where (to which service, social institution, organ)

2 and whom to address for help, support for solving the aforesaid problems? If "yes", name these institutions, specialists.

3 Do you know the neighbors who live next to you (on the floor, in the house entrance, on the street)?

From your point of view, are in Your hall (house or street)

4 families that need help (social, legal, pedagogical, psychological, medical, other), support of social services, power bodies?

When you see (know about) cases of violence or difficult

5 circumstances of children, families, are you ready to inform relevant services, authorities, institutions?

6 Did you ever help your neighbors? If "yes" how?

7 Are you ready to help in future, if one addresses to You?

The results of diagnostics of community dwellers of the city micro-districts as to their knowledge and activity and also readiness for social orphanhood prevention within neighborhood communities are presented in Fig. 1.

Analyzing the results of the interrogation of dwellers of the local communities of two micro-districts of Lugansk city (micro-districts Sazonov and Mala Vergunka), obtained at diagnostics, it must be noted that $65.8 \%$ (741 persons) of dwellers have chronic non-material problems. 
Among key complications there dominates the group of psychological-pedagogical problems that concerns communication between family-members, microclimate of a family, aggression, case of violence, addictive behavior and so on. It may be explained by not only economic-material complications, but also insufficient development level of assertive skills (passivity or aggression dominate), absence of a motivation for self-education, knowledge as to the correct solution of problems, lack of time for communication and other. In fact $20.7 \%$ (233 persons) of interrogated periodically face with this kind of problems, but have a situational personal resource (knowledge, information) as to their solution, and only $13.5 \%$ (152 persons) of citizens may be considered as resistant to such life cases and able to overcome they independently. It is typical for the last two indices that there are mainly citizens with a higher humanitarian education and rather long experience of family life and education of children.

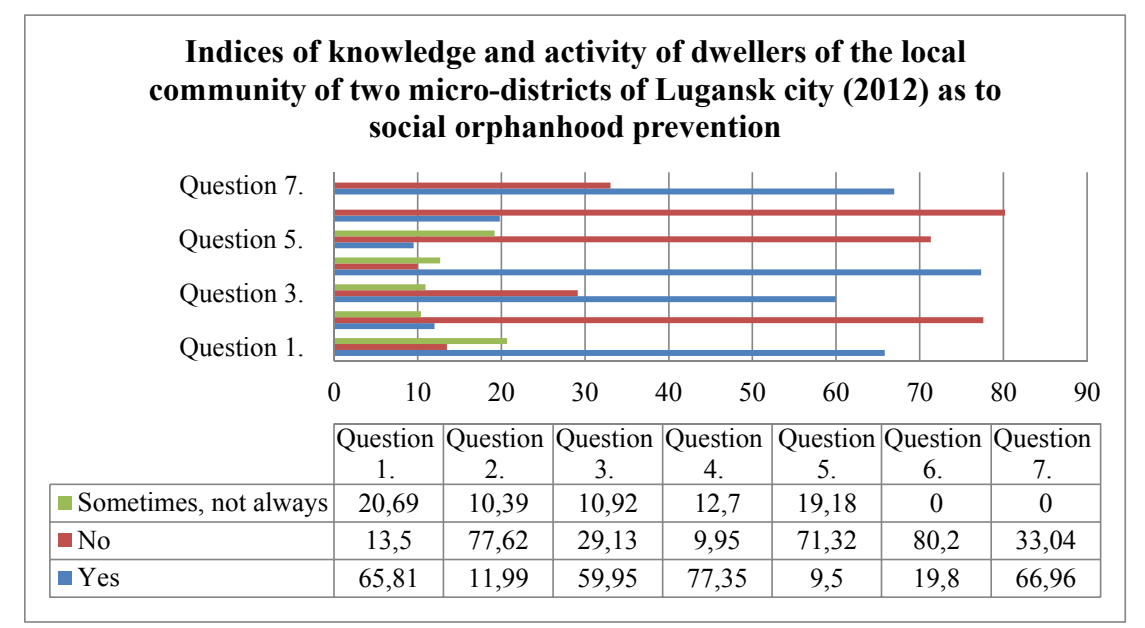

Fig. 1. Diagnostics of knowledge and activity levels of dwellers of the local community of two micro-districts of Lugansk city (2012) as to social orphanhood prevention (\%)

The other question was directed on revealing the level of knowledge of experimental micro-district dwellers as to the existent net of socio-supporting institutions of the city (district) territory community that give preventive services, and where they can address for support, help. But unfortunately, the results demonstrated that: $77.6 \%$ (874 persons) of dwellers practically don't know, just where they can get a qualified help in solving non-economic problems. $10.4 \%$ (117 persons) of interrogated possess this information only partially and can name among such social institutions, services, establishments, organs, specialists: centers of social protection; school psychologists, social teachers, class supervisors, school administration; public (secular and religious) organizations; specialists in child affairs, juridical subdivisions of local power bodies; organs of the national policy (succession is indicated according to the frequency of the obtained variants of answers). This all testifies to the lack of knowledge of micro-district dwellers about centers of socio-pedagogical and psychological support and help, if these problems appear, absence of knowledge about, what institutions, services, centers, specialists can give help, where they are located.

According to the results of answers to the third question, which aim was to elucidate a knowledge degree of representatives of neighborhood communities about each other and coordination of communicative connections between them, practically $59.95 \%$ (675 persons) of dwellers know most their neighbors and $10.92 \%$ (123 persons) partially know only faces, but don't communicate. $29.13 \%$ (328 persons) - don't know, who live besides them and are not interested. Analyzing the obtained results, we came to a conclusion that the knowledge degree and strength of communicative connections between neighborhood communities of the micro-districts depend on a duration of living at the same place (longer live besides, better know), on the presence of common affairs or interests (arrangement of the territory, common solemnities, holidays, communication between children and so on), on personal properties of an individual (communicability development). Just that is why, it is important to unite dwellers around common affairs and problems, formation of 
common interests, development of social and communicative connections for activation of resources of self-help of neighborhood communities.

The block of four-seven questions was oriented on a knowledge degree of dwellers as to each other, realization, understanding of possible problems of own neighbors and elucidation of a development degree of social empathy in representatives of a neighborhood community, their social capital (potential, resources) as to involving dwellers of neighborhood communities, micro-districts in solving existing problems. At analyzing the results of this block of questions we elucidated that $77.35 \%$ (871 persons) of interrogated know about complications in families of their neighbors, but only $9.5 \%$ (107 persons) are ready to inform relevant services, authorities, institutions. $19.8 \%$ (223 persons) have already realized an attempt to help, and $66.9 \%$ (754 persons) - are potentially ready to give help, to support, if neighbors address to them, but not initiating it independently. More detail communication with respondents demonstrated that a rather low per cent $(9.5 \%)$ of dwellers, ready to inform special institutions and establishments about possible cases of necessary help to neighbors, is connected: in first, with unwillingness "to interfere in a another family" because of a risk of negative results for themselves, their close people; at second, with a lack of distinct information, where to address, to which services, institutions, establishments; at third, with unwillingness to be "a participant of an excessive red tape", if communicating with official bodies, power institutions.

For elucidating the preventing potential of neighborhood communities of the city microdistricts, their activation in the matter of social orphanhood prevention, important indicators are the results of answers on the seventh question of the questionnaire that in fact reflects, from our point of view, a rather high social empathy potential of neighborhood community dwellers $66.96 \%$ (754 persons) and open the perspective of formation and development of the citizens' activity, at system and purposeful organization of communication with this category of dwellers.

So, based on the results, obtained at diagnostics, the next stage of the experimental-research work as to elucidating the preventing potential of the city territorial community became the analysis of the institutional space of the city territorial community by the method of its mapping.

Community mapping is a process of determining the current condition of a community that involves not only power bodies and experts, but also ordinary dwellers. It gives a possibility to estimate the resource potential of a community, to make unsolved questions public, to elaborate ideas together and to put bases of the city development. Using marks of a map, an initiative group fixes places that the attention of active citizens must be paid to [27]. In the context of this study the aim of the mapping method became creation of a map of social institutions of the city territorial community that can give both preventive services and qualified help at appearing risks of social orphanhood, life crisis of a family or its separate member. That is in fact creation of a map of the net of governmental and public institutions of the socio-supporting type that are subjects of social orphanhood prevention and informing of dwellers of the city territorial community about it.

Summarizing, it must be noted that because of objective socio-political circumstances, indicated above, the socio-pedagogical experiment on elaboration and probation of the system of socio-pedagogical social orphanhood prevention under conditions of the city territorial community, had started in 2012, was stopped in June of 2014 and continued already in March of 2015 under conditions of the territory community of Starobilsk city in the north of Lugansk region. But this is already a format of the next publication.

Today there lasts the experiments as to creating a socio-supporting environment around families and children (individuals) of a risk group of social orphanhood within city territorial communities of Lugansk, Starobilsk, Severodonetsk, Lugansk region (at interaction with representatives of public organizations, local bodies of self-government of the cities Starobilsk and Lugansk). Forces of specialists of Social centers of family strengthening and Scientific-methodical consultation center of social orphanhood prevention (functioning at the department of social pedagogy of Lugansk national university, named after Taras Shevchenko, evacuated to Starobilsk city in 2014, and also public associations realize the socio-pedagogical supervision of: 154 children of families, found themselves in difficult living conditions, 14 children of children's homes of the family type and adopted families, remained in Lugansk city; 205 children of families of internally moved per- 
sons (IMP) and 12 children of adopted families of Starobilsk region; socio-psychological consultations, educational services, humanitarian help were given to 5000 persons of IMP families.

\section{Conclusions}

Summarizing the aforesaid, the following conclusions may be made:

1. A phenomenon of social orphanhood became a negative reflection of the Ukrainian present time, and its prevention and overcoming need combining forces of the state and society, initiatives of citizens and active functioning of territorial communities, directed on solving this problem.

2. As it is demonstrated by the modern state practice of solving social problems, the system of social protection of family and childhood in Ukraine is built on the paradigm of welfare (social maintenance) and is grounded on the deficit model of social (socio-pedagogical) work [28], that provides the solution of social problems, orienting on needs of socially vulnerable categories of citizens, risk groups and giving them a necessary social help, and not on the paradigm of activation of state and society resources and personal ones of citizens themselves, orientation on strong sides of governmental and public institutions, people themselves in the process of preventing and overcoming social problems, that is on the so-called preventive strategy of social policy that is inherent to most civilized economically developed countries of the world.

3. This study doesn't exhaust all problem questions of the announced theme. An orientation point for further scientific investigations may be considered as main tasks of the plan of arrangements for realization of the national strategy of social orphanhood prophylaxis for the period to 2020 year [29], that accent attention on the importance of solving problems of introducing new social technologies of revealing families with children that are in difficult life conditions, upbringing of responsible parenthood, reintegration of pupils of boarding school institutions to biological families, involvement and activation of subjects of territorial communities into the preventive work and solution of social problems of the population of Ukraine and so on that may be a subject of further scientific studies.

\section{References}

[1] Kuleba, M. (2018). Usinovlenimi mozhut' buti ne bil'she $5 \%$ vihovanciv internativ. Available at: https://www.ukrinform.ua/rubric-society/2464791-usinovlenimi-mozut-buti-ne-bilse-5-vihovanciv-internativ-kuleba.html Last accessed: 16.06.2018

[2] Minsotspolityky: Detsentralizatsiia nadast bilshe povnovazhen hromadam u vyrishenni problem ditei iz neblahopoluchnykh simei (2017). Available at: https://www.kmu.gov.ua/ua/news/249842734 Last accessed:17.06.2018

[3] Tyonnis, F. (2002). Obshchnost' i obshchestvo. Osnovnye ponyatiya chistoi sociologii. Saint Petersburg: Izd-vo «Vladimir Dal'», 451.

[4] Bates, F. L., Bacon, L. (1972). The Community as a Social System. Social Forces, 50 (3), 371379. doi: http://doi.org/10.2307/2577041

[5] Hillery, G. A. (1955). Definitions of Community: Areas of Agreement. Rural Sociology, 20 (2), 111-123.

[6] Batanov, O. (2008). Terytorialna hromada - pervynnyi subiekt munitsypalnoi vlady v Ukraini: poniattia ta oznaky. Visnyk Tsentralnoi vyborchoi komisii, 2, 51-57.

[7] Jonassen, C. T. (1959). Community Typology. Community Structure and Analysis. New York, 20-21.

[8] Putnam, R. D. (2000). Bowling Alone: the Collapse and Revival of American Community. New York: Simon \& Schuster, 505.

[9] Shaffer, R. (1989). Community Economics. Economic Structure and Change in Smaller Communities. Iowa, Iowa State University Press. Ames, 4.

[10] Bopp, M., Bopp, G. (1998). A Practical Guide to Building Sustainable Communities. Calgary: Alberta, 168.

[11] Barker, R.; Barker, R. (Ed.) (1995). Community. The Social Work Dictionary. Washington: NASW Press, 68.

[12] Scoat, P. M. (1987). The Different Drum: Community Making and Peace. Second Touchstone Edition. New York: Simon and Shuster. 337. Available at: https://www.amazon.com/Different-Drum-Community-Making-Peace/dp/067160192X Last accessed:25.07.2017 
[13] Warren, R. L. (1963). The Community in America. Chicago: Rand McNally. 418. Available at: https://www.questia.com/read/9866569/the-community-in-america Last accessed: 26.07.2017

[14] Lelechenko, A. P., Vasylieva, O. I., Kuibida, V. S., Tkachuk, A. F. (2017). Mistseve samovriaduvannia $\mathrm{v}$ umovakh detsentralizatsii povnovazhen. Kyiv, 110.

[15] Baranovska, T. M. (2016). Derzhavna polityka rozvytku terytorialnykh hromad v Ukraini. Kharkiv, 261.

[16] Lebedynska, O., Yashchuk, L. (2015). Vzaiemodiia terytorialnoi hromady z nederzhavnymy orhanizatsiiamy shchodo profilaktyky sotsialnoho syritstva. Efektyvnist derzhavnoho upravlinnia, 42, 245254. Available at: http://nbuv.gov.ua/UJRN/efdu_2015_42_30 Last accessed: 10.11.2015

[17] Semyhina, T. V. (2004). Robota v hromadi: praktyka ta polityka. Kyiv: Vydavnychyi dim «KM Akademiia», 178.

[18] Volodina, Yu. A., Matyash, N. V., Sidorina, M. S. (2012). Deinstitutionalization of orphans in an open socio-cultural space. Moscow: Pedagogical Society of Russia.

[19] Lopatchenko, I. M. (2017). State administration of prevention of social orphanhood at the regional level. Kharkiv, 236.

[20] Protasova, T. M. (2004). Mezhvedomstvennoe vzaimodeystvie uchrezhdeniy sotsial'noy sfery v reshenii problem sirotstva na territorii. Kemerovo, 173.

[21] Kalchenko, L. V. (2018). Sotsialne syritstvo ta yoho preventsiia v terytorialnii hromadi mista: mizhvidomcha vzaiemodiia subiektiv hromady. Education and Pedagogical Sciences, 1 (168), 53-66.

[22] Kyianytsia, Z. P., Petrochko, Zh. V. (2017). Sotsialna robota z vrazlyvymy simiamy ta ditmy. P. I. Suchasni oriientyry ta kliuchovi tekhnolohii. Kyiv: OBNOVA KOMPANI, 256.

[23] Aveltseva, T. P., Kalinina, A. V., Zymivets, N. V. (2013). Mekhanizmy formuvannia ta vprovadzhennia mistsevoi sotsialnoi polityky. Robochi materialy treninhovoho kursu dlia spetsialistiv sotsialnoi sfery. Kyiv: Ukrainskyi fond «Blahopoluchchia ditei», 264.

[24] Bezpalko, O. V., Aveltseva, T. P., Matsevko, N. I. (2006). Community Activation Technologies. Kyiv: Scientific world, 95.

[25] Kokarev, I. (2001). Sosedskie soobshhestva: put' k budushhemu Rossii. Moscow: Prometey, 248.

[26] Bezpalko, O. V. (2006). Orhanizatsiia sotsialno-pedahohichnoi roboty z ditmy ta moloddiu u terytorialnii hromadi: teoretyko-metodychni osnovy. Kyiv: Naukovyi svit, 363.

[27] Minkin, Ya., Antoshchuk, Yu., Demel, G.; Soshynska Ya., Krasowska-Igras M. (Eds.) (2017). Kartuvannia hromad v Ukraini. Kyiv: UBA; Informacyjnego Fundacja Rozwoju Społeczeństwa, 111.

[28] Inglehart, R. F., Welzel, C. (2010) Modernization, cultural change, and democracy: the human development sequence. New York: Cambridge University Press, 333. doi: http://doi.org/10.1017/ cbo9780511790881

[29] Pro zatverdzhennia planu zakhodiv z realizatsii Natsionalnoi stratehii profilaktyky sotsialnoho syritstva na period do 2020 roku (2013). Kabinet Ministriv Ukrainy, No. 419-r. 27.05.2013 Available at: https://www.kmu.gov.ua/ua/npas/246453881 